ПРОФЕСІЙНА ПІДГОТОВКА МАЙБУТНІХ ЛІКАРІВ

ДО МІЖКУЛЬТУРНОЇ ВЗАЄМОДІЇ У ПРОФЕСІЙНІЙ ДІЯЛЬНОСТІ

\title{
PROFESSIONAL TRAINING OF FUTURE DOCTORS FOR INTERCULTURAL INTERACTION IN PROFESSIONAL ACTIVITIES
}

\begin{abstract}
Стаття присвячена розгляду проблеми підготовки майбутніх лікарів до міжкультурної взаємодії з представниками інших культур у подальшій професійній діяльності, фоормування в них здатності до обміну профресійним досвідом у галузі медицини з вітчизняними та зарубіжними партнерами. Розглянуто підходи сучасних дослідників до визначення сутності понять підготовка», «профресійна підготовка», «готовність майбутніх лікарів до міжкультурної взаємодії». У контексті дослідження поняття «підготовка» розуміється як цілеспрямований педагогічний процес, спрямований на набуття теоретичних знань i формування практичних умінь $і$ навичок, необхідних для здійснення майбутньої профресійно діяльності. Установлено, що важливим аспектом профресійної діяльності майбутніх лікарів виступає їхня готовність просресійно діяти в ситуаціях міжособистісної взаємодії, яка зумовлює необхідність застосування в освітньому процесі медичного закладу вищої освіти інноваційних форм і методів навчання, спрямованих формування у студентів, комунікативних умінь i навичок, що є необхідними в практичній діяльності лікаря; культури мовлення, що впливає на успіх профресійної діяльності лікаря; іншомовну підготовку, що є умовою налагодження міжнародних, ділових контактів із метою обміну досвідом, організації та проведенні досліджень у медичній ссрері; розвиток навичок професійної комунікації під час фрахової підготовки майбутніх лікарів. Подано визначення десініції «готовність майбутніх лікарів до міжкультурної взаємодії), яка розглядається як особистісний психологічний стан, що характеризується позитивною настановою на співробітниитво з представниками різних культур, встановлення з ними взаємодовірливих відносин, наявністю знань щодо традицій своєї та іншої культури, дотриманням профресійного етикету в медичній галузі, уміннями вербального і невербального спілкування, особистісними і профресійними якостями, що сприятиме здійсненню професійної діяльності на високому рівні.
\end{abstract}

Ключові слова: майбутні лікарі, підготовка, просресійна підготовка, готовність майбутніх лікарів до міжкультурної взаємодії.

The article is devoted to the consideration of the problem of preparation of future doctors for intercultural interaction with representatives of other cultures in the further professional activity, formation in them of the ability to exchange professional experience in the field of medicine with domestic and foreign partners. The approaches of modern researchers to defining the essence of the concepts of "preparation", "vocational training", "readiness of future doctors for intercultural interaction" are considered.

In the context of research, the concept of "preparation" is understood as a purposeful pedagogical process aimed at acquiring theoretical knowledge and the formation of practical skills necessary for future professional activity.

It is established that an important aspect of the professional activity of future doctors is their willingness to act professionally in situations of interpersonal interaction, which necessitates the use of innovative forms and methods of teaching in the educational institution of higher education, aimed at forming students, communicative skills practical activity of the doctor; a culture of speech that influences the success of a doctor's professional activity; foreign language training, which is a prerequisite for establishing international, business contacts with the aim of exchanging experience, organizing and conducting research in the medical field; development of professional communication skills during the professional training of future doctors. The definition of "future physicians' readiness for intercultural interaction" is defined, which is considered as a personal psychological condition, characterized by a positive attitude to cooperation with representatives of different cultures, establishing with them a trusting relationship, the presence of knowledge about the traditions of their own and another culture, adherence to professional etiquette in the medical field, skills of verbal and non-verbal communication, that will promote high-level professional activity. Key words: future doctors, training, vocational training, future doctors' readiness for intercultural interaction.
Постановка проблеми. Глобалізаційні процеси, які відбуваються в Україні на сучасному етапі розвитку суспільства, зміни в ціннісних орієнтаціях, розширення міжкультурних контактів вимагає модернізації освіти, спрямування ії на підготовку молоді до вирішення професійних завдань в умовах полікультурного середовища. Зважаючи на те, що сьогодні в закладах вищої освіти, особливо медичних, навчаються представники багатьох країн і національностей, виникає необхідність підготовки майбутніх лікарів до ефективної взаємодії з представниками інших культур в подальшій професійній діяльності, фрормування в них здатності до обміну профресійним досвідом у галузі медицини з вітчизняними та зарубіжними партнерами. Отже, формування готовності майбутніх лікарів до міжкультурної взаємодії у професійної діяльності $€$ важливим завданням закладів вищої медичної освіти.

Аналіз останніх досліджень і публікацій. Зазначимо, що проблема профресійної підготовки майбутніх лікарів не $є$ новою. Так, окремі аспекти підготовки студентів-медиків розглядаються в працях Н. Авраменко, Л. Гепенко, І. Гуменної, О. Гуменюк, О. Корж, Л. Новакової, І. Паламаренко, Л. Рибалко, Ф. Щербакової, О. Яцишиної та ін. Особливості фрахової підготовки майбутніх лікарів виступили предметом наукових розвідок 
таких дослідників, як О. Андрійчук, В. Бабаліч, П. Бабенко, І. Булах, Т. Бухарина, О. Васильєва, Л. Добровська, Г. Єпіфранцева, Л. Кайдалова, О. Кривонос, М. Кропачева, І. Кузнецова, М. Лісовий, Л. Лозинська, А. Мельник, В. Мілерян, М. Мруга, Ю. Поляченко та ін. Незважаючи на значну кількість наукових праць, присвячених питанням підготовки студентів медичних закладів вищої освіти, проблема формування готовності майбутній лікарів до міжкультурної взаємодії в професійній діяльності не була предметом окремого дослідження.

Метою статті $€$ визначення сутності понять «підготовка», «професійна підготовка», «готовність майбутніх лікарів до міжкультурної взаємодії».

Виклад основного матеріалу. В аспекті започаткованого дослідження необхідно визначити сутність понять «підготовка» і «професійна підготовка». Аналіз наукових джерел дозволив дійти висновку, що на трактування поняття «підготовка» сьогодні не існує єдиного погляду. Так, у довідникових джерелахпоняття «підготовка» тлумачиться як:

- запас знань, навичок, досвід тощо, набутий у процесі навчання, практичної діяльності [3, с. 767];

- сукупність спеціальних знань, умінь й навичок, якостей, трудового досвіду й норм поведінки, які забезпечують можливість успішної роботи 3 визначеної професії; як процес повідомлення відповідних знань й умінь [12, с. 156];

- формування та збагачення настанов, знань і вмінь, які необхідні індивіду для адекватного виконання специфічних завдань [10, с. 342];

- засвоєння певного соціального досвіду 3 метою його подальшого застосування під час виконання специфічних завдань практичного, пізнавального чи навчального характеру; як навчання, тобто як деякий спеціально організований процес формування готовності до виконання майбутніх завдань; готовність, під якою розуміють наявність компетенції, знань, умінь та навичок, необхідних для успішного виконання певної сукупності завдань [16].

За визначенням М. Васильєвої, «підготовка» - це процес фрормування, удосконалення знань, умінь, навичок, якостей особистості, необхідних для виконання діяльності, здійснюваної в ході навчання, самоосвіти або професійної освіти [2, с. 168]. Отже, на підставі вищезазначеного, поняття «підготовка» будемо розуміти як цілеспрямований педагогічний процес, спрямований на набуття теоретичних знань і фрормування практичних умінь і навичок, необхідних для здійснення майбутньої професійно діяльності.

Набуття студентами означених знань, умінь і навичок відбувається в процесі професійної підготовки в закладах вищої освіти, що має на меті поглиблене ознайомлення майбутніх фрахівців із науковими засадами майбутньої профресії; набуття спеціальних практичних навичок і вмінь; фрормування особистісних і професійних якостей особистості, необхідних для роботи в певній ссрері людської діяльності.

За твердженням Н. Ничкало, підготовка кваліфрікованих, конкурентоспроможних фрахівців із високим рівнем професійних знань, умінь, навичок і мобільності, що відповідає вимогам науково-технічного прогресу та ринковим відносинам в економіці; виховання соціально активних членів суспільства, фрормування в них наукового світосприйняття, творчого мислення, кращих людських якостей, національної свідомості $€$ головним завданням професійної освіти [8, с. 11].

У довідникових джерелах поняття «профресійна підготовка» визначається, як: процес формування фахівця для однієї з галузей трудової діяльності, пов'язаного з оволодінням певним родом занять, профресією [15, с. 381], система професійного навчання, метою якої $€$ прискорене набуття студентами навичок, необхідних для виконання певної роботи, групи робіт [9, с. 233]; сукупність спеціальних знань, умінь і навичок, якостей, трудового досвіду та норм поведінки, які забезпечують можливість успішної праці за обраною професією [16].

Дослідниками професійна підготовка розглядається як: процес професійного становлення майбутніх спеціалістів; засіб приросту індивідуального потенціалу особистості, розвитку її резервних сил, пізнавальної та творчої активності на підставі оволодіння загальнонауковими та професійно значущими знаннями, вміннями й навичками (В. Сагатовский); педагогічний процес формування в майбутніх спеціалістів спеціальних знань, умінь і навичок, відповідних норм поведінки та професійних якостей, необхідних для продуктивної діяльності (Т. Качеровська); система організаційних та педагогічних заходів, які забезпечують формування в особистості професійної спрямованості, системи знань, навичок, умінь і професійної готовності, що, в свою чергу, визначається як суб'єктивний стан особистості, яка вважає себе здатною і підготовленою до виконання певної професійної діяльності та прагне її виконати (Т. Танько).

щодо професійної підготовки майбутніх лікарів у медичних закладах вищої освіти, суголосні з визначенням Н. Авраменко, яка розглядає означений френомен як організаційно-педагогічний процес, маркований тенденцією переходу від навчальної до професійної діяльності, спрямований на фрормування в майбутніх лікарів профресійної компетентності, психологічної готовності та здатності до самовдосконалення й навчання впродовж життя [1, с. 56].

Важливим аспектом професійної діяльності майбутніх лікарів виступає їхня готовність професійно діяти в ситуаціях міжособистісної взаємодії, що зумовлює необхідність застосування в освітньому процесі медичного закладу вищої освіти 
інноваційних фрорм і методів навчання, спрямованих фрормування у студентів, комунікативних умінь і навичок, що є необхідними в практичній діяльності лікаря; культури мовлення, що впливає на успіх професійної діяльності лікаря; іншомовну підготовку, що є умовою налагодження міжнародних, ділових контактів із метою обміну досвідом, організації та проведенні досліджень у медичній сорері; розвиток навичок профресійної комунікації під час фрахової підготовки майбутніх лікарів [4, с. 47-48].

3 огляду на зазначене, у процесі навчання важливими є моделювання й аналіз ситуацій професійної комунікації, спрямованих на оволодіння студентами-медиками профресійно-комунікативними вміннями, необхідних для їхньої повноцінної фрахової діяльності в майбутньому, а саме: уміння встановлювати психологічний контакт із людьми, забезпечувати взаємини, необхідні для спільної діяльності у лікуванні; мовленнєві вміння (здатність ефективно використовувати загальновживану лексику, спеціальну термінологію та професійні слова 3 метою забезпечення успішності мовленнєвого акту, ознаками якої є змістовність, доступність, зрозумілість, доречність, різноманітність, виразність, естетичність) [14, с. 52].

Необхідним складником професійної комунікації майбутніх лікарів $€$ міжкультурна комунікація, в якій сучасний фрахівець може бути успішним лише якщо він розуміє міжкультурологічні аспекти й може застосовувати свої культурологічні знання в міжкультурній взаємодії, що за твердженням Н. Калашнік передбачає розуміння позиції співбесідника, вміння уявляти себе на його місці, розмовляти 3 ним за його правилами зі своєю метою; передбачати конфліктні ситуації на міжкультурному підґрунті; реально оцінювати власне мовлення і ділову поведінку; налагоджувати довірливий контакт із співрозмовником, створювати атмоссреру діловитості, порозуміння, приязні тощо [6, с. 155].

На думку О. Садохіна, для здійснення міжкультурної взаємодії у майбутніх фрахівців необхідно формувати міжкультурну компетентність, яка за його переконанням, $€$ сукупністю знань, навичок і вмінь, за допомогою яких індивід може успішно спілкуватися з партнерами з інших культур як на побутовому, так і на професійному рівні [13, с. 133] і передбачає надання студентам знань про міжкультурні взаємовідносини та фрормування в них навичок толерантної взаємодії, співпраці з представниками різних культур, рас та віросповідань на принципах взаєморозуміння, взаємоповаги та терпимості [5, с. 78].

Розглядаючи готовність студентів до міжкультурної взаємодії, І. Козубовська і Д. Данко виокремлюють декілька їі аспектів:

- психологічна готовність - передбачає наявність позитивної мотивації до міжкультурного спілкування, усвідомлення наявності відмінних якостей, властивостей та особливостей у кожного 3 учасників міжкультурної взаємодії; позитивна настанова на співробітництво і фрормування довірливих відносин у процесі взаємодії),

- теоретична готовність - характеризується наявністю необхідної системи знань про культуру, традиції, особливості вербального і невербального спілкування в конкретному полікультурному середовищі),

- практична готовність - свідчить про ссрормованість в індивіда умінь і навичок здійснення есрективної міжкультурної взаємодії.

3 урахуванням означеного, готовність до міжкультурної взаємодії дослідники визначають як особистісний стан, який передбачає наявність у суб'єкта образу, структури дії та постійної спрямованості свідомості на їі успішне виконання. Він містить мотиви, орієнтовані на усвідомлення завдань, моделі ймовірної поведінки, побудовані у відповідності 3 наявними знаннями, визначення спеціальних способів діяльності, оцінку можливостей у їх співвіднесенні 3 можливими майбутніми труднощами та необхідністю досягнення певного позитивного результату [7, с. 137].

У контексті започатковано дослідження значний інтерес має розуміння готовності майбутніх лікарів до міжкультурної комунікації як позитивної настанови на співробітництво і фрормування довірливих робочих відносин у процесі комунікативної взаємодії; знання про свою та іншу культуру, традиції, особливості вербального і невербального спілкування комунікантів; уміння ефективної комунікативної взаємодії, що забезпечуються сорормованими особистісними й професійними якостями фрахівців [11, с. 262].

Готовність майбутніх лікарів до міжкультурної взаємодії розглядаємо як особистісний психологічний стан, що характеризується позитивною настановою на співробітництво $з$ представниками різних культур, встановлення з ними взаємодовірливих відносин, наявністю знань щодо традицій своєї та іншої культури, дотриманням професійного етикету в медичній галузі, уміннями вербального і невербального спілкування, особистісними і профресійними якостями, що сприятиме здійсненню профресійної діяльності на високому рівні.

Висновки. Підсумовуючи, доходимо висновку, що фрормування готовності майбутніх лікарів до міжкультурної взаємодії є важливим складником їхньої профресійної підготовки і потребує забезпечення цілеспрямованої роботи, спрямованої на набуття студентами теоретичних знань і практичних навичок щодо означеного феномена, набуття досвіду організації комунікативних ситуацій міжкультурної взаємодії під час навчання в медичних закладах вищої освіти. Перспективу подальших наукових розвідок убачаємо у визначенні компо- 
нентної структури готовності майбутніх лікарів до міжкультурної взаємодії в професійній діяльності.

\section{БІБЛІОГРАФІЧНИЙ СПИСОК:}

1. Авраменко Н.О. Підготовка майбутніх лікарівіноземців до оволодіння професійною термінологією у медичних закладах вищої освіти : дис. канд. пед. наук : 13.00.04. Хмельницький, 2019. 354 с.

2. Васильєва М. Теоретичні основи деонтологічної підготовки педагога : дис... докт. пед. наук : 13.00.04. Харків, 2003. 432 с.

3. Великий тлумачний словник сучасної української мови / уклад. і гол. ред. В.П. Бусел. Київ : Ірпінь: ВТФ «Перун», 2005. 1728 с.

4. Гуменна І.Р. Особливості підготовки майбутніх лікарів до професійної комунікації. Науковий вісник МНУ імені В.О. Сухомлинського. Педагогічні науки. 2015. № 1 (48). 2015. С. 100-104.

5. Довгополова Я.В. Толерантні відносини студентів у полікультурному середовищі. Реалізація принципів і завдань Болонського процесу в Україні : матеріали міжнар. наук. конфр. Львів, 2005. C. 76-82.

6. Калашнік Н.В. Застосування міжкультурного тренінгу у фрормуванні міжкультурної комунікативної компетентності іноземних студентів - майбутніх медиків. Наукові записки. Серія: педагогіка. 2016. № 1. С. 154-158.

7. Козубовська І.В., Данко Д. В. Формування готовності іноземних студентів-медиків до міжкультурного спілкування. Науковий вісник Ужгородського національного університету. Серія:
Педагогіка. Соціальна робота. 2017. Вип. 1 (40). C. $136-138$.

8. Ничкало Н.Г. Неперервна професійна освіта як фрілософська та педагогічна категорія. Неперервна профресійна освіта : теорія і практика. 2001. Вип. 1. С. 9-22.

9. Педагогический энциклопедический словарь / гл. ред. Б.М. Бим-Бад; редкол. : М.М. Безруких, В.А. Болотов, Л.С. Глебова и др. Москва : Большая Российская энциклопедия, 2002. 528 с.

10. Педагогічний словник / за ред. М.Д. Ярмаченка. Київ : Пед. Думка, 2001. 514 с.

11. Рибалко Л.С., Гепенко Л.О. Міжкультурне виховання як складова профресійної підготовки майбутніх лікарів у закладах вищої медичної освіти. Наукові записки кафедри педагогіки. Вип. 44. 2019. C. 256-268.

12. Российская педагогическая энциклопедия / под. ред. А.М. Прохорова. Москва: Науч. изд-во «Большая Российская энциклопедия», 1999. Т. 2. 423 с.

13. Садохин А.П. Межкультурная компетентность : понятие, структура, пути фрормирования. Журнал социологии и социальной антропологии. Санкт-Петербург, 2007. Т. Х. № 1. С. 125-139.

14. Скубашевська О.С. Мовні стратегії інноваційної освіти. Вища освіта України. 2007. № 4. С. 51-55.

15. Тлумачний словник сучасної української мови : близько 50000 слів / уклад. І.М. Забіяка. Київ : Арій, 2007. 512 c.

16. Энциклопедия профессионального образования : в 3 т. / под ред. С.Я. Батышева. Москва : АПО, 1998. URL: http://www.anovikov.ru/dict/ epo.pdf. 